

\title{
Harnessing History: Narratives, identity and perceptions of Russia's post-Soviet role
}

\author{
P N Chatterje-Doody \\ University of Manchester
}

Russian political elites have long been aware of the power of myths to forge national unity. However, the past six or seven years have seen core myths increasingly situated within a highly selective narrative of Russian history. This narrative is accepted as contextual information for policy discussion, and so sets cognitive parameters for evaluations of Russia's history, identity and role. This standard narrative of Russian history prioritises the state, supports gradualism and continuity, and dramatically reduces the potential for reconceptualising Russia's role in contemporary international relations.

Key words: narrative, identity, myth, history, Russia

\section{Introduction}

Nations and governments frequently evoke ideas of shared history in order to help forge collective identities, and promote feelings of group loyalty and cohesiveness (Riessman and Quinney, 2005, p. 393; Wertsch, 1997; Anderson, 1991;). Consequently, political elites often compete to present national histories, and therefore shared identities, in ways that support their preferred policy objectives (Wodak et al., 1999). Recent Russian experience provides a particularly interesting case study. Firstly, Russia's postSoviet 'identity crisis' has resulted in numerous elite state- and nation-building initiatives from the ruling elite (Stent, 2008; Smith, 2002; Smith, 1999; Urban, 1998). Secondly, though competing histories exist in all kinds of political systems, the contemporary Russian ruling elite's account is subject to limited challenge, due both to the media's prioritisation of elite activities and rhetoric, and its limited freedom to present challenges to the political elite's narrative. Existing work on Russia has examined elite references to national identity (Hopf, 2005; Mukharyamov, 2004; Tishkov, 1997; Chafetz, 1996/7), historical narratives and collective 'memory' (Chapovskii, 2011; McAuley, 2011; Wood, 2011; Sherlock, 2007; Smith, 2002; Urban, 1998) and the reproduction of certain modes of elite discourse (Urban, 2010; Miller, 2009). However, the use of more precise typologies can help to consolidate this research, by enabling the application of clear analytical methods. This paper relies upon a specific understanding of historical narrative in order to adapt sociological approaches to narratives of personal experience. It argues that attention to the chronologies implied in texts can yield insights overlooked by methods which reduce narratives to themes. This approach reveals how Russia's ruling elite has consciously mobilised a selective version of history that has become widely accepted as the factual context for discussions of Russian identity and national policy, limiting the scope for reconceptualising Russia's post-Soviet role.

\section{Approaching narrative analysis}

Definitions of narrative vary widely. Some take a highly formal approach to structural characteristics, identifying features such as abstract, orientation, complicating action, evaluation, resolution and coda as common elements of narrative (e.g. Labov, 1972). Other approaches are so broad that they almost 
conflate narrative with all text, with some authors referring to the recurrent themes within a text as narratives. Such a broad notion obscures more than it clarifies, so this paper insists upon certain shared characteristics of narrative to help systematise the analysis. Simply put, a narrative is a story, with some kind of plot. More specifically, although a narrative need not be told in chronological order, its subject will be implied to have both a sequential and consequential, ordering: earlier episodes are presented as having impacted upon that which followed (Riessman and Quinney 2005; Johnstone 2001; Riessman 1993). An examination of the entire narrative is therefore vital in order to make sense of how these judgements regarding chronology and causality are expressed through the links between sentences (Schiffrin et al., 2001, p. 10).

Many academic accounts that purport to analyse narratives often split information for analysis by theme, which destroys this information about context and sequence. For instance, existing literature on Russian elite narratives tends to take events such as the Second World War and explore the way they are represented (e.g. Wood, 2011; Sherlock, 2007; Smith, 2002). Yet this negates the particular explanatory potential of narrative analysis. By contrast, this paper questions which episodes elites choose for such reimagination within their grand narrative of Russian history, and uses a technique which preserves a narrative's judgements regarding sequence and consequence. As no narrative could hope to represent all stories for all occasions, the episodes within a narrative are necessarily selected from an almost infinite bank of events, so selection is significant for historical representation. Memory is, by definition, shared only by participants in an event, so historical shared 'memory' depends upon the articulation, and acceptance, of stories about those events (Bell, 2003), which come to take on the status of historical fact (Linde, 2001). The understanding of narrative used here refers to such structured stories about the past. A 'myth', by contrast, is seen as a far more general characterisation in which one or more value-judgements are presented as being established truths. Stalin's representation of war as combining peace keeping, heroism, duty and sacrifice (1941) led to the myth of him as the heroic leader to victory. This myth so helped to legitimise the ruling elite that even Khrushchev's de-Stalinisation drive referred to established themes of victory and self-sacrifice, presenting the story as one of the positive achievements of Stalin's chequered record (1956). More recently, Monaghan's reference to the 'narrative of Putin as a strong leader' (2012, p. 3) is better described as a myth. Historical narratives are stories about the past. They invariably contain multiple individual myths, but the distinction is important from a methodological perspective, since narrative analysis is appropriate only for narratives, not individual myths.

This paper analyses three core political texts from the top of Russia's ruling elite, examining the extent to which historical evaluations contribute to their political discussions. The first text, Nationalisation of the future (2006), was written by Vladislav Surkov, a critical figure in the creation of the pro-Putin United Russia party, and the key architect of ideology in Putin's first two terms (2000-2004; 2004-2008). When Putin (2005) advocated ideology-building without any specific recommendations, Surkov came up with 
the idea of 'sovereign democracy', fleshed out in this article. Surkov's work was aimed at an educated Russian audience, advocating patriotism, national unity, and national sovereignty within the international system as a prerequisite of democracy. His reassignment to the role of Deputy Prime Minister in December 2011 was variously interpreted as a sign of political change and as a meaningless gesture to appease protesters. Former President Dmitry Medvedev is variously viewed as Putin's loyal 'consigliere' (Kryshtanovskaya, 2010, p. 130), or an ineffective would-be liberal. His 2009 article, Go, Russia! was designed for public consumption, advocates liberal modernisation and supports international cooperation and industrialisation as a route to democracy. The final article, Russia muscles up, was the first of seven newspaper articles published by Vladimir Putin in response to increasing domestic unrest from the end of 2011 onwards, prior to the Presidential elections of March 2012. It presents a general vision of Russia that Putin promises to expand upon in his later articles, which are not suitable for inclusion here since they are dedicated to specific policy areas.

As the analysis reveals, each of these texts presents an historical narrative, by making frequent reference to historical episodes, and implying a chronological and consequential relationship between them which is seen as bearing continued relevance for Russia's identity and role. Given the importance of the selection and presentation of particular events, this paper attempts to achieve a systematic examination of the narratives by first considering their implied chronologies - in effect, the decisions regarding which events are considered significant enough to include. It also considers the evaluative statements made about such events, revealing how certain episodes are linked both to recurring identity themes and broader value judgements. Although some themes recall those of Soviet times or the Yeltsin era, they are situated within a standard narrative that incorporates very specific episodes (historical and recent) and evaluates them using extremely similar images and linguistic formulations. Where Yeltsin-era rhetoric criticised Soviet radicalism and the high price paid for societal developments, contemporary discourse extends similar evaluations to the Yeltsin period itself, and presents these within a clear historical narrative built from a formulaic set of chronologies, images and rhetoric. Narrative analysis of these texts reveals not only that readings of history are being employed in the service of politics, but that one very limited, specific historical narrative has emerged. It prioritises the state and champions continuity, helping set the parameters within which Russian identity and its global role can be articulated.

\section{Vladislav Surkov's Nationalisation of the future}

The consumption of narratives is highly contingent on their circumstances, audience and context (Riessman and Quinney, 2005, p. 398). Putin's first presidential term (2000-2004) was presented as purely pragmatic, with national interest at the core of foreign policy, and historically sensitive policies advocated over Yeltsin's revolutionary reforms (Okara, 2007, p. 1). Despite Putin's strategic approach to energy, a 'grand systemic project' of modernisation was absent (Okara, 2007, p. 1). However, second term (20042008) legacy concerns saw Putin advocate ideology-building for future development (Putin, 2005). The 
specifics were left to Vladislav Surkov, the deputy head of the Presidential administration, described by oligarch Mikhail Prokhorov as the Kremlin 'puppet master' (Pomerantsev, 2011).

Published in Ekspert, a magazine favoured by the business and political classes, Nationalisation of the future outlined Surkov's concept of 'sovereign democracy' on the eve of the United Russia party's 2006 congress. He probably sought to help unify the party's electoral messages, and to consolidate public support for the ruling elite (Okara, 2007, p. 2). The article stresses the importance of national history and Russian identity for Russia's future development, since for Surkov, Russia's great history necessitates a nationally distinct, great future $(2006$, paras. 71,88$)$. Surkov ties the evolution of a distinctive Russian identity to a unique historical development through Tsarism, socialism, and oligarchy (2006, para. 25). Each stage leads closer to a destination yet to come, with Russia retaining its distinctive identity within globalisation processes (2006, para. 26).

Surkov uses historical focal points to introduce specific themes, thereby generating a narrative of Russia's history, told in a thematic-episodic rather than continuous format (Riessman and Quinney, 2005). After noting that ancient democracy would not have satisfied contemporary definitions, Surkov refers to damaging cultural habits from Russia's distant past (2006, para. 41) and characterises Peter the Great's reign using the recurring paradox of development and despotism. He then jumps to a limited characterisation of the pre-20th century period, highlighting the negative consequences of totalitarianism, and the war years. Interestingly, the 1990s and the present day receive the greatest amount of narrative focus. After referencing the challenges of the secession period, including its institutional implications, Surkov's narrative reaches the present day, which he frequently compares, albeit vaguely, to the previous elements of his narrative.

Certain themes are repeated throughout, such as the historic coexistence of modernisation and development with despotism and tragedy, the European experience of technological advancement through tragedy, and the (ethnic) Russian tolerance, that has characterised Russia's regional leadership through history, presented normatively unproblematically as the context for the piece (Surkov, 2006, para 77). Despite admitting to 'monstrous mistakes and sacrifices' of Russian modernisation (2006, para. 17), Surkov emphasises that ethnic Russians (russkie) initiated democratic transformations during both Imperial and Soviet times that benefitted their entire sphere of influence (2006, paras. 17, 76). By crediting ethnic Russians for peaceful ethnic, linguistic, cultural and religious cohabitation (2006, paras. 72, 76), Surkov's narrative implies their ongoing regional duty.

Nonetheless, Surkov explicitly rejects contemporary hegemonic aspirations for Russia or other countries (2006, para. 22). Instead, he contextualises soft power and international co-operation within Russia's historic regional leadership, implying their usefulness for maintaining regional influence. Surkov's 
narrative simultaneously foregrounds Russia's role as a co-founder of European civilisation (2006, para. 44, para. 80), and he calls for Russia to maintain global influence (2006, para. 10), without losing sovereign identity within a 'multi-ethnic euronation' (2006, paras. 29-30). He compares Russia's historic growth through strength model to the implicit weakness of (presumably Western-leaning) client-type states, whose sovereignty he sees as compromised in a way impossible for an inherently strong Russia: 'another kind of durable power is unthinkable here' (2006, para. 35).

Surkov emphasises Russia's historic uniqueness, advocating culturally distinct thoughts, values and goals as potential sources of national unity (2006, paras. 59-60). He cites the dangers of the post-Soviet secession period (2006, para. 72), linking state integrity to a coherent multinational identity, with nationbuilding a priority. He presents cultural movements as sources of patriotism (2006, para. 61), which is intriguing, as the article was written when programmes of nation-building and great power restoration were being consolidated, including the framing of Russian nationhood around the state rather than ethnocultural belonging, and less critical representations of Stalin in history textbooks and the broader domestic context (Wood 2011, 179; Mikhaleva 2010, p. 16). Surkov's approach to national unity focuses on the state's achievements, and tempers praise of the Russian peoples' characteristic strength, dignity and audacity (2006, para. 10, para. 17), with criticism of their 'political slovenliness' (2006, para. 43) and preference for 'ruinous and ruthless governmentalisation' (2006, para. 50).

Surkov's narrative combines leitmotifs of contemporary democracy with traditional values of patriotism, order, stability, great powerism, regional leadership, global influence, and modernisation without Westernisation. It consequently supports continuity in Russia's political regime, which is unsurprising, given Surkov's affiliation. According to this account, a particular historical experience is the source of a unique Russian identity that defines Russia's particular future. Although Surkov rejects a return to historical models, his vision of future strategy relies upon this highly specific vision of Russia's past, and particularly his narrative of gradual linear development.

\section{Dmitry Medvedev's Go, Russia!}

Published online in September, 2009, just over a year into Medvedev's Presidency, this article proposes a path for Russia's development. Domestically and internationally, the article was overwhelmingly interpreted as an attempt to demonstrate liberal values (it was published simultaneously in Russian and English). The political content of Go, Russia! rests upon reflections on Russia's historical role. Despite intense debate over whether elites instrumentalise national history and identity in Russia (Hopf, 2005; Mukharyamov, 2004; Malakhov, 1998; Tishkov, 1997; Chafetz, 1996/7), Medvedev explicitly links Russia's history to future policy decisions, making an appreciation of his narrative crucial for understanding his policy objectives. 
Structurally, Go, Russia! displays all six of Labov's (1972) formal elements of narrative - abstract, orientation, complicating action, evaluation, resolution and coda. The abstract (Russian version only) declares that Medvedev will assess Russia's strategic goals, and invites citizen participation in the debate over the country's future. Medvedev evokes historical orientation points, such as the forthcoming 'new decade of the twenty-first century' (2009, para. 1) and 65 th anniversary of Victory in the Great Patriotic War' to help him 'reflect on the past, evaluate the present, and think about the future' (2009, para. 2). This orientation contextualises his complicating actions, which include Russia's primitive economy and culture of paternalism, and which are expanded in a series of rhetorical questions, such as 'What will be Russia's place, and hence the place of our... future generations... in the system of international relations...?' (2009, para. 5). Medvedev emphasises continuity with the past, asserting that 'our present day is the future of the heroes who won our freedom' (2009, para. 3), implying an historical continuum for a state-based, rather than ethno-national, in-group. This collective myth is perpetuated through frequent use of the in-group signifiers 'us', 'we' and 'our', which again link the people to the state's existence over time: 'We the contemporary generation of the Russian (rossisskie) people, have received a huge inheritance' (2009, para. 4). Medvedev's many historical illustrations form the outline of his thematic-episodic narrative.

Medvedev's account of the distant past is limited. He acknowledges ancient democracy, characterises Russia's past as centuries of underdevelopment and corruption, and refers to Peter I's paradox of development through despotism. After mentioning overcoming $19^{\text {th }}$ century illiteracy and serfdom, as well as international coalition defeat of Napoleon, his main focus is the $20^{\text {th }}$ century, including Soviet developmental paradoxes and wartime victory. There is a subsequent narrative gap until the 1990s, a period characterised as combining democracy, tragedy, tumult and paralysis. With the exception of the Georgian war, Medvedev's narrative presents another void between Russia's secession period and the time of writing. He characterises the present as a unique time of unique opportunities, but analyses it using historical references or comparisons, such as the anniversary of military victory, or stability in comparison to the 1990s. When debating Russia's current place in the world, Medvedev emphasises Russia's greatness and need to protect its historical heritage. In this context, he highlights the potential for strength within partnerships and coalitions (2009, paras. 47-56).

Whilst Medvedev advocates learning from the past to inform Russia's future development, his limited selection of historical focus points and associated themes enables him to omit challenging aspects of Russia's history. Medvedev thereby restricts the myths from which historical lessons can be drawn, with corresponding policy implications. For instance, though he admits to negative consequences of the Imperial and Soviet rounds of modernisation, 'the two greatest modernisations in our country's history... [which] unleashed ruin, humiliation and resulted in the deaths of millions' (2009, para. 24), he passes no 
further judgement. Instead, he repeats the theme of development, with an emphasis on persuasion, international co-operation, harmonisation of interests and other soft power tactics. Medvedev presents Russia's future prospects as the continuation of his narrative along a linear trajectory, tacking industrial development and democratic reform on to his narrative of gradual development in which bold modernisations are accompanied by social collateral damage. He implies that systemic failings were sideeffects of past rounds of modernisation and development, with setbacks inevitable on the road to future development. This promotes caution rather than urgency in reform.

Despite Medvedev's reiteration of his commitment to democratic modernisation, narrative analysis reveals how his selective treatment of history presents Russia's future development as contingent on particular lessons from the past. These lessons emphasise continuity over time, and prioritise collective achievements in the presence of adversity. Medvedev highlights the fine line between developmental triumph and disaster, necessitating careful control, with the state guaranteeing citizens' rights during the development process. Direct criticisms of state power are historically situated, enabling a deferral of government culpability. Rather than a liberal manifesto, Go, Russia! is better read as a case for gradualism and stability.

\section{Vladimir Putin's Russia muscles up}

Putin's article in the popular daily Irvestia was seen as the ruling tandem's most politically salient publication since Go, Russia! (Babich, 2012). Coming at a time of widespread domestic protest, it might be expected to present a shift in rhetoric, but demonstrates significant similarities with the earlier articles not least in its reliance on particular representations of history to further specific political points.

This article also displays Labov's six formal narrative characteristics, presenting a salient quotation as an initial abstract, and using the presidential elections of March $4^{\text {th }}$ as its orientation point (2012c, para. 1). This is followed by complicating actions, or 'risks and challenges', articulated in a series of rhetorical questions about Russia's future place in the world: 'Will we follow the course of events or take a role in setting the rules of the game? What resources will help us to strengthen our positions...?' (2012c, para. 2). The main body of the article evaluates the contemporary situation and its implications, followed by the resolution, which rests upon Russia's capacity to 'muscle up' to face future challenges (2012c, paras. 69$71)$.

Throughout the article, Putin references historical episodes and associated judgements, producing a thematic-episodic narrative which underpins his policy discussion. His rather vaguely defined past begins with 'centuries of cooperation with the East' (2012c, para. 54), and a well-established tradition of respecting 'the state, public interest and the nation's needs' (2012c, para. 34). Historic problems include the absence of 'deep-rooted democratic traditions, popular political parties and a mature civil society' 
(2012c, para. 59) and recurrent elite attempts to achieve revolutionary rather than gradual change (2012c, para. 3). Putin's chronology sharpens on the 'peak' of the USSR's development in 1989, rapidly followed by its dissolution, and the shock, recession and degradation of the 1990s, when the Russian state's temporary weakness was seized upon by separatist elements (2012c, para. 57). He then jumps to his own role (beginning as Prime Minister) in facilitating a decade of economic growth following the 1998 financial crisis, and the economic diversification initiatives that have helped Russia to weather the most recent financial storm. He characterises the present day as a time of tremendous opportunity (2012c, para. 65), in which the post-Soviet phase of history has ended, the 'recovery period is... over', and greater public engagement is necessary for a reinvigoration of politics (2012c, para. 64).

As a long-term advocate of learning from the past to avoid repeating mistakes (Putin, 2004; Putin, 2000), it is notable that Russia's future appears highly contingent in this article: 'Russia can and must play a role predicated upon its civilisation model, its great history, geography and its cultural "genome" (Putin, 2012c, para. 54). It seems clear that Putin's representation of history in this specific way displays instrumentalist motivations. This is reflected in his recognition of Russia's historic European and Eastern orientations (2012c, para. 54), with calls for international cooperation during the transition from unipolarity to multipolarity (2012c, para. 51), accompanied by the preservation of national sovereignty.

The linked importance of sovereignty and national unity recurs throughout the article, and focuses on the state rather than the population. Putin cites how Russia's lack of democratic tradition meant that the restoration of national unity in the 1990s demanded the establishment of Russian sovereignty (2012c, para. 60). He rejects any justification for the violation of international law or the principle of sovereignty (2012c, para. 53). Whilst noting the recent growth in social, ethnic and cultural tensions (2012c, para. 52), he advocates the potential role of Russia's main religions - Orthodoxy, Islam, Judaism and Buddhism - to help build trust and resolve societal conflicts (2012c, para. 38).

Putin reserves a special role for structures of authority over the people. He questions the population's commitment to politics (2012c, para. 7), and criticises the passivity (2012c, para. 31) that he sees as borne of mistrust and a lack of self-confidence (2012c, paras. 34-35), presenting them as challenges for democracy. He asserts that 'Personal freedom is productive only if one looks out for others. Freedom which is not based on morality turns into anarchy' (2012c, para. 39). Similarly, Putin notes that the 'absolute majority of Russians (rossiyan) wants to see their country strong and powerful' (2012c, para. 34) and credits the government with the 'steady growth in Russia's wealth in the past decade' (2012c, para. 24), thanks to programmes of economic diversification since 2008 (2012c, para. 25).

Despite representing his article as 'an invitation to join... a dialogue' about Russia's future (2012c, para. 11), Putin displays obvious scepticism about the public's capacity to accept. He also sets clear parameters 
to the possible futures for Russia, given their apparent contingency on a past that combines the primacy of the state over individuals with a preference for 'stable development' (2012c, para. 2) and gradualism over more dramatic change. Putin notes that 'Russia comes through any ordeal and is always victorious' (2012c, para. 70). Regardless of its political context and overt calls for civic engagement, Putin's narrative displays a multi-layered case for patient acceptance of the domestic status quo.

\section{Comparisons}

On the surface, these texts vary significantly in terms of length, structure, value judgements and resultant policy and role recommendations. However, they display significant similarities with regards to history, narratives, and ultimately political judgements. Their sensitivity to historical representations follows a trend established by Marxism-Leninism, which aimed to achieve a scientific approach to history through 'objective' assessment of history. For instance, Khrushchev sought to aid de-Stalinisation by compiling, 'in accordance with scientific Marxist objectivism, a textbook of the history of Soviet society' (1956). This tendency resonates today, in debates over government-approved Russian history textbooks (Chapovskii, 2011; Mikhaleva, 2010), and the establishment of the short-lived Commission on Countering Attempts to Falsify History in a Manner that Damages Russia's interests. Set up by Medvedev ostensibly to counter foreign subversion of 'objective' accounts of Soviet war conduct (Mikhaleva, 2010), the commission was symbolic, rather than practical, and was quietly disbanded in 2012 (Malinova, 2012a, p. 9).

Given that all three authors have presented critical analysis of the past as necessary for avoiding repeated mistakes, their critiques are rather limited. They all demonstrate consciousness of the potential for collective stories to create in-group unity, so it is significant that they focus on many of the same events, and evaluate these events using the same themes and values associated with Russian identity. Surkov and Medvedev mention classical democracy, whilst noting its limitations, and all authors note the negative habits of Russia's past. Surkov and Medvedev present Peter the Great's reign as combining tragedy inevitably with advancement. References to the war period recycle established Soviet-era themes, including heroism, duty and self-sacrifice (Stalin, 1941), and their potential to result in great achievements, despite despotism and loss (Khrushchev, 1956). This aside, coverage of the twentieth century is scant, until the detailed characterisation of the 1990s as turbulent, and the present day as stable in comparison. All three narratives emphasise Russia's longevity and continuity, its positive inheritances, cultural uniqueness and its historical vulnerability to the dangers of radicalism.

These texts exclude countless alternative focal points that could be used for presenting a parallel historical narrative, including the founding of Moscow University, the reforms of the 1860s, or the 1905 revolution and attempt at parliamentarism (Malinova, 2011, p. 118). They therefore represent the standardisation of history in which preferred themes and images are expressed in uncannily similar style and rhetoric. Each author represents the time of writing as unique, and full of new opportunities (Putin, 2012c, para. 50; 
Medvedev 2009, para. 25; Surkov 2006, para. 45). In presenting a case for gradualism, they echo Yeltsin's (Izvestia, 1993, p. 30) mistrust of radical ideology (Putin, 2012c, para. 3) or dismiss it as 'fashionable hypotheses' (Surkov 2006, para. 30) and 'abstract theories' (Medvedev, 2009, para. 37). All three authors develop medical representations of longstanding social problems as curable diseases (Putin, 2012c, para. 33; Medvedev, 2009, para. 21; Surkov, 2006, para. 49). In justifying Russia's continued influence in the world, both Surkov and Putin stress Russia's role in the development of European civilisation (Putin, 2012c, para. 56; Surkov, 2006, para. 58).

Though each article attests to the 'dignity' of the Russian people (Putin, 2012c, para. 70; Medvedev, 2009, para. 16; Surkov 2006, para. 10), they instrumentalise people as constituting the economic potential for the state's development, and Surkov and Medvedev overtly label them 'intellectual resources' (Putin, 2012c, para. 29; Medvedev, 2009, paras. 46, 30; Surkov, 2006, paras. 82, 91). All link the development of a knowledge economy with political development (Putin, 2012c, para. 26; Medvedev, 2009, para. 32; Surkov, 2006, para. 92), but firmly emphasise sovereignty, which must not be violated for even 'the noblest of intentions' (Putin, 2012c, para. 53). Russia must 'become stronger and reinforce [its] status in this rapidly changing world' (Putin, 2012c, para. 73), 'without weaselling or giving in to pressure to conform' (Medvedev, 2009, para. 50) and should 'say what it will do and not do what is said by others' (Surkov, 2006, para. 58).

Attempts at increasingly liberal rhetoric by Medvedev and Putin mask recycled representations of certain historical events, used to present similar conclusions about the nature of politics. The precise imagery used often bears striking similarities, and this is most evident in some of the specific word choices of Surkov and Medvedev, leading to speculation that Surkov authored both texts. For instance, in echoing the idea from Yeltsin's inaugural address of the price paid for development (Izvestia, 1993, p. 30), they specify the price in terms of human lives (Medvedev, 2009, para. 24; Surkov, 2006, para. 42), and whilst reiterating Putin's admission of deficiencies in Russia's democracy (2000, para. 6; 2012c, para. 7), they contend that it is, nonetheless, 'working' (Medvedev, 2009, para. 15; Surkov, 2006, para. 52). Whilst impossible to dismiss, such speculation does not alter the fact that each of these texts was presented and endorsed by its nominal author. Despite some echoes of established rhetorical themes, these articles go further. They formulate their arguments around a very particular narrative, demonstrating how acceptance and propagation of a standard reading of history pervades the top levels of Russia's ruling elite.

Surface differences between the preferred political themes within these texts are primarily cosmetic and related to differences in the Kremlin's strategic approach when each was written. Surkov sought to ensure United Russia's electoral unity, Medvedev was writing with party unity consolidated, to try to ensure regime continuity beyond the 2008 Presidential elections, and Putin's article had to hint at a more inclusive political future following widespread discontent. Both Medvedev and Putin imply a change in 
era, with their invitations to political dialogue (Putin, 2012c, para. 11; Medvedev, 2009, para. 1). Medvedev praises defeating serfdom and illiteracy, but makes no substantial diversion from the hegemonic narrative - perhaps because of restrictions inherent in the tandem power model (Malinova, 2012b). Putin promotes multipolarity and hints at a more liberal approach, with caveats discussed earlier. Yet in all three texts, the 'signature' themes and associated value-judgements are tied to a specific narrative. They employ standardised terms, and also provide new images which are so similar as to infer a broader political project, in which standardised reporting and evaluation of Russia's past is used to support particular political value judgements. One standard historical narrative underlies official political discussion.

Russia's historical role of power, strength and regional leadership is presented as a guideline for its future trajectory. The standard narrative sets Russia at the centre of social and political developments in its geographical region, with a corresponding duty as the first among equals. At the same time, Russia's European identity and equal role in the development of European civilisation is noted. Historic cooperation is cited to promote continued European co-operation. Yet this is tempered by the prioritisation of Russia's sovereignty, together with acknowledgements of the soft power implications of international co-operation. These relationships are presented as a means to an end for Russia, rather than an end in themselves. Similarly, the call for economic modernisation and development in these texts is tied to political outcomes. These recommendations are all made with a close eye on the potential political capital to be made, specifically for strengthening the Russian state's position on the international stage.

The primacy of the nation state is constantly reiterated within the standard narrative. The state provides the site for the definition of a stable, continuous in-group community, and frequent mention of its historical and contemporary uniqueness renders it an effective anchor for patriotic focus. Non-state actors are consistently subordinated to the state itself - the peoples' moral deficiencies concern their preferred patterns for the state's political organisation, their moral qualities developed in symbiosis with the multinational nature of the state, and their intellectual capabilities are not individual qualities, but potential economic capital for the state.

\section{Conclusions}

Russian intellectual history has a long tradition of debate over national identity. Previous attempts to use historical interpretations as the foundation for ideal-type national characteristics have enabled some historical and identity myths to become so well-established over time that they are now unconsciously parroted as fact. Alternative interpretations become almost impossible, as with Stalin's victory myth. Consequently, elite representations of a few specifically reproduced national myths display clear similarities. With renegotiation of such longstanding myths remaining highly problematic, attention to the chronologies implied in these texts raises questions over why non-interpretable events are consistently 
chosen for contemporary narratives. It has been argued that this reflects elite reluctance to engage with difficult aspects of the past for fear of damaging societal unanimity (Malinova, 2011). Occasionally, narrative supplements (Medvedev's abolition of serfdom, or Putin's post-Soviet separatist threat) reveal a little more of the author's position. However, the overwhelming similarities in inclusion and, critically, interpretation of events (such as the chaotic 1990s) suggest that narrative standardisation results more from design than pure iteration. The stylistic and rhetorical similarities between the texts also support this explanation.

Systematic attention to the chronologies of elite historical narratives helps to reveal how the overt nationbuilding initiatives of the early Putin period have evolved to a more sophisticated level, to play a major role as the context for discussing political strategy. Although some discursive themes echo those from earlier periods, they are now being situated within a standard narrative of history that creates the impression of being a factual account. The overwhelming similarities in the chronologies, images and rhetoric of these texts demonstrate how the specifics of the narrative have been consciously set. This restricts the range of possibilities for elite articulation of Russia's policy objectives and role in the world. These superficially different approaches to Russian politics reflect their time of writing, but combine a restrictive range of historical plot points with standard values and themes that present Russia's future options as contingent upon a specific past. Russia's nature is essentialised, as is its historic and future role. Putin's policy-oriented pre-election articles of 2012 further demonstrate this trend, emphasising Russia's long history and uniqueness (Putin, 2012b; Putin, 2012d), its culture of tolerance and interethnic harmony derived from multinational statehood (Putin, 2012d), and the value of state strength and patriotism (Putin, 2012a). The Russian elite's standard historical narrative shows no signs of abating, and it supports continuity in political power and approach, associates development with collateral damage, and conceptualises Russia's international identity as being dictated by its history of great power, regional leadership, duty, and pragmatic co-operation.

Russia's identity and role is being viewed through a limited and rigorously controlled lens of its history, which prioritises the state above all else, situates the contemporary ruling elite at the centre of the state's survival processes and leaves very little room for tolerance of challenges to Russia's leading role in its region, or to perceived slights to Russia's international status. Given the strength and monopoly of the historical narrative that underlies these characterisations, the potential for reconceptualising Russia's role in contemporary international relations is dramatically reduced. In this context, we are likely to witness the continuation of neo-colonial characteristics in Russia's relations with its neighbours, insistence on an identifiable, often dissenting Russian voice in global organisations, limited partnership with Europe on specific, pragmatically defined key interests, and the prioritisation of international partnerships with rising global powers. 


\section{Bibliography}

Anderson, B. (1991) Imagined Communities: Reflections on the origin and spread of nationalism, London: Verso.

Babich, D. (2012) 'Putin Segodnya, Medvedev vchera... Rossiya vpered!' RLA Novosti [online]. Available from: http://ria.ru/analytics/20120116/540847491.html [Accessed 26 April 2013].

Bell, D. S. A. (2003) 'Mythscapes: memory, mythology, and national identity', The British Journal of Sociology, 54 (1), pp. 63-81.

Chafetz, G. (1996/7) 'The struggle for a national identity in post-Soviet Russia', Political Science Quarterly, 111 (4), pp. 661-688.

Chapovskii, F. (2011) 'Uchebnik istorii i ideologicheskii defitsit', Pro et Contra, 15 (1-2), pp. 117-133.

Hopf, T. (2005) 'Identity, legitimacy, and the use of military force: Russia's great power identities and military intervention in Abkhazia', Review of International Studies, 31 (S1), pp. 225-243.

Izvestia (1993) 'Iz vystupleniya B N 'Eltsina pri vystuplenii v dolzhnost' prezidenta Rossiiskoi Federatsii 10 Iiulya 1991 g.' in B. I. Koval' (ed.), Rossiya Segodnya: Politicheskii Portret v dokumentakh 1991-1992. Moscow: Mezhdunarodnoe Otnoshenie, pp. 29-30

Johnstone, B. (2001) 'Discourse Analysis and Narrative' in D. Schiffrin, D. Tannen \& H. Hamilton (eds.), The Handbook of Discourse Analysis. Oxford: Blackwell Publishing Limited, pp. 635-649

Khrushchev, N. (1956) Speech to the 20th Congress of the CPSU, 24th-25th February 1956 - Transcript [online]. Available from: www.marxists.org/archive/khrushchev/1956/02/24.htm [Accessed 15 March 2012].

Kryshtanovskaya, O. (2010) 'The Russian Elite in Transition' in R. J. Hill \& O. Campbell (eds.), Putin and Putinism. Abingdon, Oxon.: Routledge, pp. 115-134

Labov, W. (1972) Language in the City: Studies in the Black English Vernacular, Philadelphia: University of Pennsylvania Press.

Linde, C. (2001) 'Narrative in Institutions' in D. Schiffrin, D. Tannen, \& H. Hamilton, (eds.), The Handbook of Discourse Analysis. Oxford: Blackwell Publishing Limited, pp. 512-536

Malakhov, V. S. (1998) 'Neudobstvo s identichnostiu', Voprosy filosofii 2.

Malinova, O. (2011) 'Tema proshlogo v ritorike prezidentov Rossii', Pro et Contra, 52, pp. 106-122.

Malinova, O. (2012a) 'Politics of identity and political uses of the past in Russia'. Paper presented at BISA-ISA Diversity in the Discipline: Tension or Opportunity in Responding to Global Challenges, Edinburgh, 20-22 June.

Malinova, O. (2012b) 'Simvolicheskoe edinstvo natsii?', Pro et Contra, 55, pp. 76-93.

McAuley, M. (2011) 'Istoricheskaia pamyat' i obshchestvo sograzhdan', Pro et Contra, 15 (1-2), pp. 134-149.

Medvedev, D. A. (2009) 'Rossiya Vpered!' Gazeta [online]. Available from: http://www.kremlin.ru/transcripts/5413 [Accessed 04 May 2011].

Mikhaleva, G. (2010) 'Overcoming the totalitarian past: foreign experience and Russian problems' Russian Analytical Digest, 72, pp. 16-19.

Miller, A. (2009) 'Rossiya: vlast' i istoriya', Pro et Contra, 13 (3-4), pp. 6-23.

Monaghan, A. (2012) 'The vertikal: power and authority in Russia', International Affairs, 88 (1), pp. 1-16.

Mukharyamov, N. M. (2004) 'Ethnicity and the study of international relations in the post-soviet Russia', Communist and Post-Communist Studies, 37 (1), pp. 97-109.

Okara, A. (2007) 'Sovereign Democracy: A New Russian Idea or a PR Project?', Russia in Global Affairs, (3).

Pomerantsev, P. (2011) 'Putin's Rasputin', London Review of Books [online], 33 (20). Available from: http://www.lrb.co.uk/v33/n20/peter-pomerantsev/putins-rasputin/print [Accessed 15 February 2012].

Putin, V. V. (2000) Inaugural Speech [online]. Available from: http://archive.kremlin.ru/eng/text/speeches/2000/05/07/0002 type82912type127286 128852. shtml [Accessed 14 March 2012].

Putin, V. V. (2004) Inaugural Address [online]. Available from: http://archive.kremlin.ru/eng/text/speeches/2004/05/07/1255 type82912type127286 64132.s html [Accessed 14 March 2012].

Putin, V. V. (2005) Annual Address to the Federal Assembly of the Russian Federation [online]. Available from: http://archive.kremlin.ru/text/appears/2005/04/87049.shtml [Accessed 20 July 2011]. 
Putin, V. V. (2012a) 'Byt' sil'nymi: garantii natsional'noi bezopasnosti dlya Rossii', Rossiiskaya Gazeta, [online], 20 February. Available from: http://premier.gov.ru/events/news/18185/ [Accessed 02 August 2012].

Putin, V. V. (2012b) 'Demokratiya i kachestvo gosudarstva', Kommersant, [online], 6th February. Available from: http://premier.gov.ru/ events/news/18006/ [Accessed 02 August 2012].

Putin, V. V. (2012c) 'Rossiya sosredotachivaetsya - vyzovy, na kotorye my dolzhny otvetit', Izvestia, [online], 16th January. Available from: http://premier.gov.ru/events/news/17755/ [Accessed 02 August 2012].

Putin, V. V. (2012d) 'Rossiya: Natsionalny vopros' Nezavisimaia Gazeta, [online], 23rd January. Available from: http://premier.gov.ru/events/news/17831/ [Accessed 02 August 2012].

Riessman, C. K. (1993) Narrative Analysis, London: Sage Publications Limited.

Riessman, C. K. \& Quinney, L. (2005) 'Narrative in social work', Qualitative Social Work, 4 (4), pp. 391-412.

Schiffrin, D., Tannen, D. \& Hamilton, H. (2001) 'Introduction' in D. Schiffrin, D. Tannen, \& H. Hamilton, (eds.), The Handbook of Discourse Analysis. Oxford: Blackwell Publishing Limited, pp. 110.

Sherlock, T. D. (2007) Historical narratives in the Soviet Union and post-Soviet Russia: destroying the settled past, creating an uncertain future, Basingstoke: Palgrave Macmillan.

Smith, G. B. (ed.) (1999) State-Building in Russia: The Yeltsin Legacy and the Challenge for the Future, London: M E Sharpe.

Smith, K. E. (2002) Mythmaking in the new Russia: politics and memory during the Yeltsin era, London: Cornell University Press.

Stalin, J. V. (1941) Radio Broadcast on July 3rd, 1941 - Transcript [online]. Available from: www.marxists.org/reference/archive/stalin/works/1941/07/03.htm [Accessed 15 March 2012].

Stent, A. (2008) 'Restoration and Revolution in Putin's Foreign Policy', Europe-Asia Studies, 60 (6), pp. 1089-1106.

Surkov, V. I. (2006) 'Natsionalizatsia budushchego' Ekspert, 43 (537) [online]. Available from: http://expert.ru/expert/2006/43/nacionalizaciya buduschego/ [Accessed 11 May 2011].

Tishkov, V. (1997) Ethnicity, Nationalism and Conflict in and After the Soviet Union: The Mind Aflame, London: Sage Publications Limited.

Urban, M. (1998) 'Remythologising the Russian state', Europe-Asia Studies, 50 (6), pp. 969-992.

Urban, M. (2010) Cultures of power in post-communist Russia: an analysis of elite political discourse, Cambridge: Cambridge University Press.

Wertsch, J. V. (1997) 'Narrative tools of history and identity', Culture \& Psychology, 3 (1), pp. 5-20.

Wodak, R., De Cillia, R., Reisigl, M. \& Liebhart, K. (1999) The discursive construction of national identity, Edinburgh: Edinburgh University Press.

Wood, E. A. (2011) 'Performing Memory: Vladimir Putin and the Celebration of World War II in Russia', The Soviet and Post-Soviet Review, 38 (2), pp. 172-200. 